\title{
Impact of Financial Risk Management Practices on Financial Performance: Evidence from Commercial Banks in Botswana
}

\author{
Sathyamoorthi C. R. ${ }^{1}$, Mogotsinyana Mapharing ${ }^{1}$, Mphoeng Mphoeng ${ }^{1}$, Mashoko Dzimiri ${ }^{1}$ \\ ${ }^{1}$ Faculty of Business, University of Botswana, Gaborone, Botswana \\ Correspondence: Sathyamoorthi C. R., Faculty of Business, University of Botswana, Gaborone, Botswana.
}

Received: November 22, 2019

Accepted: December 10, 2019

Available online: December 12, 2019

doi:10.11114/afa.v6i1.4650

URL: https://doi.org/10.11114/afa.v6i1.4650

\begin{abstract}
The study examined the impact of financial risk management practices on the financial performance of commercial banks in Botswana. The study used Return on Assets and Return on Equity to measure financial performance. Inflation, Interest rates, total debt to total assets, total debt to total equity, total equity to total assets and loan deposit ratios were used as proxies for financial risk management. The research population was all the 10 commercial banks in Botswana and the study covered a period of 8 years from 2011 to 2018. This descriptive study sourced monthly secondary data from Bank of Botswana Financial Statistics database. Descriptive statistics, correlation and regression analyses were applied to analyze the data. The results from regression analysis showed that interest rates had a negative and significant impact on return on assets and on return on equity. On the other hand, total debt to total assets showed a negative and insignificant effect on return on assets. However, total debt to total assets, revealed a positive and insignificant effect on return on equity. The loan deposit ratio indicated a negative and significant impact on return on assets and on return on equity. Findings suggest that banks should strike a proper balance between financial risk management practices and financial performance by engaging in appropriate market, credit, and liquidity risk management practices that will ensure safety for their banks and yield positive profits.
\end{abstract}

Keywords: financial risk, return of assets, return of equity, commercial banks, Botswana

\section{Introduction}

The issue of impact of financial risk management on financial performance has seen an extensive amount of empirical investigation in the recent years. The subsequent myriad of such studies signify the important role played by the financial system of a country as a foundation of a functioning and efficient economy. At the heart of an economy's financial system is the banking industry; which in developing countries; is the biggest player in the role of financial intermediation (Hawkins and Mihaljek, 2001). However, Mutukua (2016) postulates that all banks operate in an unstable and fragile environment and confront various risks which may, in one way or the other, lead to the closure of a commercial bank as a result of inability to meet its financial obligations. More importantly, Shah (2014) denotes that in the financial system, there are at least three broad categories of risks being; financial risk, business risk and operational risk. Further, and as noted by Carey (2001), these risk exposures have made banking a business of risk, hence efficient risk management is critical to the survival of commercial banks.

Despite the perceived positive role of risk management on improving bank financial performance, studies in this area have offered inconsistent results. In one end of the spectrum are studies that assert a positive relationship and among others: Kenya (Maritim, 2013; Mwangi, 2014); United Kingdom (Saeed and Zahid, 2016); Nigeria (Adeusi, Akeke, Adebisi \& Oladunjoye, 2014; Olamide, Uwalomwa, and Ranti, 2015). The positive role of risk management on bank performance could be seen in terms of better management of funds, and reducing unnecessary costs such as doubtful advances (Mutukua, 2016). At the opposite end are those studies that stress that a negative relationship exits: India (Shetty and Yadav, 2019); Kenya (Muteti, 2014; Juma and Atheru, 2018). The negative relationship could be due to less leverage and risk taking, as risk management practices get tightened and this reduces bank profitability.

In developing economies, where financial sophistication is low, banks play the primary role of moving capital from households to businesses with productive purposes. It is, therefore, imperative that this role is efficient and is maximized to ensure growth in the economy. A large part of this role, therefore, is to assess risks of potential projects and businesses in the economy and appropriately price them to ensure that the projects are correctly funded and 
structured, whilst making the investments worthwhile for the funding bank. Therefore, one of the bank's biggest functions is striking the balance of correctly assessing and managing risk whilst creating sustainable profits and value for shareholders (Sinha, 2011).

This particular balance has become increasingly more important in the past 10 years since the Financial Crisis. According to Bank of International Settlements (2018), the 10 years prior to 2008 saw unprecedented growth in the world economy and financial services, largely fueled by risk taking as bankers took more and more risky positions in the pursuit of profits and bonuses. This dis-incentivized banks to do proper risk assessment on projects and that led to the melt down in 2008 which resulted in a global crisis which stalled economies and wreaked havoc on financial markets across the globe. Since then, a greater emphasis and oversight has been placed on risk management at banks and has resulted in passing of regulatory legislation, Basel III, which has called for increased risk management.

Basel III, which had its first version published in 2009 by the Basel Committee on Banking Supervision, is grounded in three main principles to counteract the ills, which causes the financial crisis. The regulation called on for increased minimum capital requirements to absorb possible shocks to a bank's balance sheet, introduced measures to cushion banks as their balance sheets evolved and introduced new regulation on leverage and liquidity management to manage possible excessive borrowing and risky behaviors by banks (Bank of International Settlements, 2011).

As expected, the effects of this regulation have been broad and far reaching. The Committee on the Global Financial System Report Number 60 found that in the decade after the Financial Crisis, the banking sector has evolved. There have been changes in market capacity and structure as most banking sectors shrank, business models have changed with a move away from trading and complex structuring to less capital intensive activities like commercial banking, and across the world, banking profitability has fallen as a result of less leverage and risk taking, but also as a result of a slow-down in most economies during that period (Bank of International Settlements, 2018). The challenge, therefore, across the world, is for banks to manage their risks and avoid another crisis whilst remaining profitable and using their capital as efficiently as possible.

\subsection{Commercial Banks in Botswana}

Botswana's banking sector has not been immune to the above challenge of increased risk management. The regulatory and supervisory oversight by the Bank of Botswana, which is the regulator of all commercial banks and related institutions, continued to focus on ensuring good governance and appropriate risk-taking by regulated institutions. The banking sector was adequately capitalized, profitable and liquid as at December 31, 2018, and the industry's compliance with the regulatory and prudential requirements was satisfactory (Bank of Botswana Annual Report, 2018).

According to Banking Supervision Annual Report (2018), the number of licensed commercial and statutory banks remained at ten and three, respectively, in 2018, employing, in total, 5270 people compared to 5210 in 2017. Banks continued to improve products and service offerings to remain relevant to the demands of the economy and sustain viable and profitable operations due to increased competition in the banking sector, along with evolving customer needs.

Meanwhile, total assets for the banking sector increased by 9.4 percent from P83.5 billion in 2017 to P91.3 billion in 2018, while customer deposits rose by 8.9 percent from P63.6 billion in 2017 to P69.3 billion in 2018, constituting 75.8 percent of liabilities (Banking Supervision Annual Report, 2018). Similarly, loans and advances increased by 7.7 percent from P54.2 billion to P58.3 billion in the same period, faster than the 5.6 percent growth in the prior year and in consequent, the financial intermediation ratio eased from 85.2 percent in 2017 to 84.2 percent in 2018 (Banking Supervision Annual Report, 2018). Notwithstanding, core indicators of financial sector depth and development show that the country's banking sector is relatively small in relation to GDP.

In terms of capital adequacy, banks largely reported capital adequacy and common equity Tier 1 capital ratios in excess of the respective 15 percent and 4.5 percent prudential and statutory minimum requirements, though one bank, had a capital adequacy ratio (of 13.3 percent) which is below the prudential minimum requirement of 15 percent as at December 31, 2018 (Banking Supervision Annual Report, 2018). With regard to credit risk, generally the composite credit risk for the banking sector was considered high and is expected to increase in the short- to medium-term due to the dominance in banks' loan books of the household sector credit, which is mostly unsecured. This makes the banking sector vulnerable to business restructuring and employment risks, particularly for state-owned entities. In the meantime, the return on equity (ROE) and return on average assets (ROA) increased from 12.6 percent and 1.4 percent in 2017 to 16.1 percent and 1.9 percent, respectively in 2018. (Banking Supervision Annual Report, 2018). This indicates that the financial performance ratios were satisfactory over the period and were in line with international norms for banks of comparable size.

However, in an environment of faster annual growth in credit during the year, the banking asset quality, as measured by non-performing loans, deteriorated marginally. In particular, the ratio of non-performing loans to gross total loans and 
advances increased from 5.3 percent in 2017 to 5.5 percent in 2018, reflecting, to a significant extent, financial distress in some segments of the business sector (Banking Supervision Annual Report, 2018).

Overall, though the banking sector is sound, there are still issues of high credit risk, banking sector being relatively small in relation to GDP, and that the overall estimation shows that the degree of financial sector development and depth has been largely static in the past five years.

\subsection{Problem Statement}

Though studies in this topic yielded inconsistent results, the positive role of risk management towards improving financial performance of banks had been evident in most studies as highlighted in literature. Since the Financial Crisis in 2007-2009, the role of risk management has become increasingly more important. With the introduction of Basel III in 2009, tighter regulations have been put in place in so far as they relate to increased minimum capital requirements, new measures to cushion banks as their balance sheets evolved, and introduced new regulation on leverage and liquidity management to manage possible excessive borrowing and risky behaviors. With the tighter regulations, changes in market capacity and structure has evolved as most banking sectors shrank, and business models have changed with a move away from trading and complex structuring to less capital intensive activities (Bank of International Settlements, 2018). The end result was that the world banking profitability has fallen as a result of less leverage and risk taking. Furthermore, this was as a result of a slow-down in most economies during that period. This outcome, therefore, leads to a research question of how risk management practices have affected banks in developing economies such as Botswana, where financial sophistication is low and risk management is imperative in order to boost profits. This study is also expected to unravel the inconsistencies of results in developing nations and also add to a scanty literature therein.

\subsection{Significance of the Study}

The study has both managerial and academic implications. It is important as it evaluates the effect of financial risk management on the financial performance of commercial banks in Botswana. The study will be of great benefit to management, as it will assist in identifying and controlling the components of financial risks that affect the financial performance of the commercial banks. The study will also help policy makers, as it will throw light on critical components that impact financial performance of the selected financial institutions, thereby enabling formulation of relevant policies. The findings will be of assistance to stakeholders and prospective investors as the study explains critical risk components that influence organizations' financial performance. The study also contributes to the existing literature on the topic.

\subsection{Objectives of the Study}

The main objective of the study is to measure the impact of financial risk management practices on the financial performance of commercial banks in the Botswana banking sector. The specific objectives were:

1. To assess the effect of market risk management practices on the financial performance of commercial banks in Botswana

2. To assess the effect of credit risk management practices on the financial performance of commercial banks in Botswana

3. To assess the effect of liquidity risk management practices on the financial performance of commercial banks in Botswana

Based on the above specific objectives and reviewed literature, the following hypotheses are developed:

$\mathrm{H}_{1}$ : Market Risk management practices have a negative and significant statistical impact on the financial performance of commercial banks in Botswana.

$\mathrm{H}_{2}$ : Credit Risk management practices have a negative and significant statistical impact on the financial performance of commercial banks in Botswana.

$\mathrm{H}_{3}$ : Liquidity Risk management practices have a negative and significant statistical impact on the financial performance of commercial banks in Botswana.

\subsection{Theoretical Review}

There are a number of theories that validates the impact of financial risk management on financial performance. A proper appreciation of such theories by an organization's management will enable them to engage in the most appropriate financial risk management practices that will suit the organization. Two of those theories are discussed below: 


\subsubsection{Finance Distress Theory}

According to Baldwin and Scott (1983, p.505), "when a firm's business deteriorates to the point where it cannot meet its financial obligations, the firm is said to have entered the state of financial distress. The first signals of distress are usually violations of debt covenants coupled with the mission or reduction of dividends". It is a condition in which an individual or a corporate fails to generate income or revenue as they fail to meet their contractual debt financial obligations. In such a situation, in a corporate context, the enterprises' financial performance deteriorates, leading to challenges in rising finance and building credibility. From the perspective of commercial banks, inability to honour deposit withdrawals and loan disbursements constitute liquidity risk. Similarly, a credit risk situation arises when the banks have non-performing loans resulting from borrower's delay in setting their loans. It therefore follows that banks should be vigilant to take care of their liquidity as well as credit risks to avoid any financial distress. According to Whitaker (1999), corrective actions by firm management to improve upon its financial performance are activated by financial distress. The financial distress theory, therefore, is relevant to the study on the relationship between financial risk management and financial performance as it identifies liquidity and credit risks as forecasters of financial distress (Wamalwa and Mukanzi, 2018).

\subsubsection{Shiftability Theory of Liquidity}

Harold G, Moulton in 1915, developed Shiftability theory (El-Chaarani, 2019). The theory states that banks should invest some of their funds available for investment in securities and credit instruments that have secondary market so that they can be converted to cash as and when a need arises to address declining liquidity. The theory contends that highly marketable securities held by banks is an excellent source of liquidity and that shiftability, marketability or transferability of a bank's assets is a basis for ensuring liquidity (Ibe, 2013). The theory further contends that highly marketable security held by a bank is an excellent source of liquidity. The theory is relevant to a study that focuses on the effect of financial risk on financial performance as it provides a clear explanation as to how liquidity risk affects financial performance using liquidity coverage and net stable funding ratios as stated by new Basel III framework (Olalekan, Mustapha, Irom \& Emily, 2018).

\subsection{Empirical Literature Review}

Academicians and researchers have assessed the impact of financial risk management on the financial performance of organizations in various sectors. Empirical evidences and results of previous studies show a mixed trend on the effect of financial management risk components on the profitability with statistically significant (negative/positive), weak and in some cases with insignificant or no impact of financial risk management practices on financial performance. The literature also indicates that researchers have used a wide variety of proxies for the components of financial risk management that included non-performing loan ratio, loan to total deposit ratio, interest rates, capital adequacy ratio, growth in interest earnings and loan loss provisions to total loans, total debt to equity, non-performing loans to gross loans ratio, Inflation, total debt to total assets, total equity to total assets etc. Return on assets and return on equity were widely used to measure financial performance. The following table provides a bird's eye view of the findings of some studies on the topic:

Table 1. Summary of findings in prior studies

\begin{tabular}{|c|c|c|c|}
\hline & Authors & Financial Risk proxies & Findings \\
\hline 1 & Shetty and Yadav (2019) & $\begin{array}{l}\text { interest rate risk and foreign } \\
\text { exchange risk }\end{array}$ & $\begin{array}{l}\text { Inverse relationship between financial risk and } \\
\text { profitability }\end{array}$ \\
\hline 2 & Noor (2019) & $\begin{array}{l}\text { credit, liquidity market and } \\
\text { foreign exchange risks }\end{array}$ & $\begin{array}{l}\text { Positive and significant impact on the financial } \\
\text { permanence }\end{array}$ \\
\hline 3 & Mardiana and Dianata, (2018) & $\begin{array}{lrr}\text { Capital } & \text { adequacy } & \text { ratio, } \\
\text { operating } & \text { efficiency } & \text { and } \\
\text { non-performing loans } & \end{array}$ & $\begin{array}{l}\text { Significant but negative impact of operating efficiency } \\
\text { on return on assets, capital adequacy ratio and } \\
\text { non-performing loan had a negative and insignificant } \\
\text { impact on ROA }\end{array}$ \\
\hline 4 & Matayo and Muturi (2018) & Operational and market risks & Significant effect on the financial performance \\
\hline 5 & Mudanya and Muturi (2018) & $\begin{array}{l}\text { Credit risk, market risk and } \\
\text { liquidity risk }\end{array}$ & $\begin{array}{l}\text { Strong relationship between profitability and credit risk; } \\
\text { a strong correlation between profitability and market risk } \\
\text { and a statistically significant relationship between } \\
\text { profitability and liquidity risk. }\end{array}$ \\
\hline
\end{tabular}




\begin{tabular}{|c|c|c|c|}
\hline 6 & Lelgo and Obwogi (2018) & $\begin{array}{l}\text { credit risk, liquidity risk, interest } \\
\text { rate risk and exchange rate risk }\end{array}$ & $\begin{array}{l}\text { Credit risk and interest rate risk negatively influenced } \\
\text { the financial performance; liquidity risk and exchange } \\
\text { rate risk had positive impacts on financial performance. }\end{array}$ \\
\hline 7 & Juma and Atheru (2018) & $\begin{array}{l}\text { Liquidity risk, credit risk, } \\
\text { interest rate risk and foreign } \\
\text { exchange risk }\end{array}$ & $\begin{array}{l}\text { Positive and significant relationship between liquidity } \\
\text { risk and return on assets and interest rate and return on } \\
\text { assets; a negative and significant relationship between } \\
\text { credit risk and return on assets and foreign exchange risk } \\
\text { and return on assets. }\end{array}$ \\
\hline 8 & $\begin{array}{l}\text { Wamalwa and Mukanzi } \\
\text { (2018) }\end{array}$ & $\begin{array}{l}\text { Credit risk, capital risk, liquidity } \\
\text { risk, interest rate risk }\end{array}$ & $\begin{array}{l}\text { Credit risk and capital risk management had a positive } \\
\text { significant impact; liquidity management practice and } \\
\text { interest rate risk management had a negative with no } \\
\text { significant impact on the financial performance. }\end{array}$ \\
\hline 9 & Balungi (2018) & Credit risk & $\begin{array}{l}\text { Strong correlation between credit risk management and } \\
\text { financial performance }\end{array}$ \\
\hline 10 & Serwadda (2018) & $\begin{array}{l}\text { Non-performing loans, growth } \\
\text { in interest earnings and loan loss } \\
\text { provisions to total loans }\end{array}$ & Credit risk management influence the performance \\
\hline 11 & $\begin{array}{l}\text { Kalu, Shieler and Amu, } \\
(2018)\end{array}$ & $\begin{array}{l}\text { Credit risk: credit risk } \\
\text { identification, credit risk } \\
\text { appraisal, credit risk monitoring } \\
\text { and credit risk mitigation }\end{array}$ & $\begin{array}{l}\text { Credit risk identification and credit risk appraisal have a } \\
\text { strong positive relationship on financial performance. } \\
\text { Credit risk monitoring and credit risk mitigation have a } \\
\text { moderate positive relationship with financial } \\
\text { performance. }\end{array}$ \\
\hline 12 & Bagh, Khan, and Sadaf, (2017 & $\begin{array}{l}\text { Capital adequacy ratio, } \\
\text { operational risk, non-performing } \\
\text { loans, interest rate risk and } \\
\text { liquidity risk. }\end{array}$ & $\begin{array}{l}\text { Risk management practices have significant impact on } \\
\text { financial performance }\end{array}$ \\
\hline 13 & Chipa and Wamiori’s (2017) & $\begin{array}{l}\text { Liquidity risk, operational risk } \\
\text { and enterprise risk }\end{array}$ & $\begin{array}{l}\text { All independent variables significantly influence the } \\
\text { financial performance }\end{array}$ \\
\hline 14 & Harelimana, (2017) & $\begin{array}{l}\text { Credit risk, operational risk, } \\
\text { liquidity risk and interest rates }\end{array}$ & $\begin{array}{l}\text { Strong relationship between risk management practices } \\
\text { and financial performance }\end{array}$ \\
\hline 15 & Saeed and Zahid (2016) & Credit risk & $\begin{array}{l}\text { Positive relationship found between credit risk and } \\
\text { performance }\end{array}$ \\
\hline 16 & $\begin{array}{l}\text { Perinpanathan } \\
\text { Vijeyaratnam (2015) }\end{array}$ & $\begin{array}{l}\text { Credit risk: Capital adequacy, } \\
\text { asset quality, management } \\
\text { efficiency, earnings and } \\
\text { liquidity }\end{array}$ & $\begin{array}{l}\text { Earnings had a strong positive and capital adequacy, } \\
\text { management efficiency, liquidity and asset quality had a } \\
\text { negative relationship with financial performance. }\end{array}$ \\
\hline 17 & Iyakaremye (2015) & $\begin{array}{l}\text { Debt to equity, debt ratio and } \mathrm{Z} \\
\text { prime }\end{array}$ & $\begin{array}{l}\mathrm{Z} \text { prime had the most significant impact; debt to equity } \\
\text { ratio and debt ratio had some impact on the financial } \\
\text { performance. }\end{array}$ \\
\hline 18 & $\begin{array}{l}\text { Olamide, Uwalomwa, and } \\
\text { Ranti, (2015) }\end{array}$ & $\begin{array}{l}\text { Non-performing loan ratio, } \\
\text { capital ratio, loan to total deposit } \\
\text { ratio and risk disclosure }\end{array}$ & $\begin{array}{l}\text { Coefficient of non-performing loan; loan to deposit, risk } \\
\text { disclosure and total asset exhibited an inverse } \\
\text { non-significant relationship, whereas capital risk showed } \\
\text { a positive insignificant relationship with the return on } \\
\text { equity. }\end{array}$ \\
\hline 19 & $\begin{array}{l}\text { Adekunle, } \\
\text { Agbatogun and Abimbola } \\
(2015)\end{array}$ & Credit risk & $\begin{array}{l}\text { Significant effect of credit risk management on financial } \\
\text { performance }\end{array}$ \\
\hline 20 & Arif and Showket, (2015) & $\begin{array}{l}\text { Management risk, solvency risk, } \\
\text { liquidity risk, underwriting risk }\end{array}$ & $\begin{array}{l}\text { Management risk, solvency risk, liquidity risk, } \\
\text { underwriting risk, influence performance }\end{array}$ \\
\hline 21 & Yousfi (2015) & credit risk, market risk, & Positive and significant impact of market risk and a \\
\hline
\end{tabular}




\begin{tabular}{|c|c|c|c|}
\hline & & $\begin{array}{l}\text { liquidity risk and operational } \\
\text { risk }\end{array}$ & $\begin{array}{l}\text { negative and significant impact of credit, liquidity and } \\
\text { operational risk management practices on return on } \\
\text { assets. }\end{array}$ \\
\hline 22 & Haque and Wani, (2015) & $\begin{array}{l}\text { credit, capital, solvency, interest } \\
\text { rate and liquidity risks }\end{array}$ & $\begin{array}{l}\text { Significant impact of credit, capital and solvency risks } \\
\text { on the financial performance; interest rate and liquidity } \\
\text { risks did not show any significant effect. }\end{array}$ \\
\hline 23 & Alshatti (2015) & $\begin{array}{l}\text { Credit risk: capital adequacy } \\
\text { ratio, credit interest /credit } \\
\text { facilities ratio, facilities loss/net } \\
\text { facilities ratio, leverage ratio and } \\
\text { non-performing loans/gross } \\
\text { loans ratio }\end{array}$ & $\begin{array}{l}\text { Positive effect of non-performing loans/gross loans ratio } \\
\text { on financial performance, a negative impact of facilities } \\
\text { loss/net facilities ratio on return on assets, no effect of } \\
\text { capital adequacy ratio and credit interest/credit facilities } \\
\text { ratio on return on assets, showed an impact of credit } \\
\text { interest/credit facilities ratio and the leverage ratio on } \\
\text { return on equity. }\end{array}$ \\
\hline 24 & $\begin{array}{l}\text { Nair, Purohit and Choudhary } \\
\text { (2014) }\end{array}$ & $\begin{array}{l}\text { Various dimensions of risk } \\
\text { management }\end{array}$ & $\begin{array}{l}\text { Risk assessment analysis, risk management practices, } \\
\text { risk identification and credit risk assessment influence } \\
\text { business performance }\end{array}$ \\
\hline 25 & Muteti, (2014), & $\begin{array}{l}\text { Liquidity risk, credit risk, } \\
\text { interest rate risk, foreign } \\
\text { exchange risk }\end{array}$ & $\begin{array}{l}\text { A negative relationship between liquidity risk, credit } \\
\text { risk, interest rate risk and foreign exchange risk and } \\
\text { financial performance }\end{array}$ \\
\hline 26 & Mwangi (2014) & All components of risk & $\begin{array}{l}\text { Strong positive relationship between risk management } \\
\text { and financial performance }\end{array}$ \\
\hline 27 & $\begin{array}{l}\text { Adeusi, Akeke, Adebisi \& } \\
\text { Oladunjoye, (2014) }\end{array}$ & $\begin{array}{l}\text { Cost of bad and debt loan, } \\
\text { non-performing loan, liquidity, } \\
\text { equity-loan asset, debt equity } \\
\text { ratio, equity-total asset and } \\
\text { managed fund }\end{array}$ & $\begin{array}{l}\text { Inverse relationship between return on capital } \\
\text { employed/return on assets/return on equity/ and cost of } \\
\text { bad and debt loans. Debt-equity ratio, on the other hand } \\
\text { showed a positive and significant relationship with all } \\
\text { the dependent variables. Managed funds had a positive } \\
\text { and significant relationship with all dependent variables. }\end{array}$ \\
\hline 28 & Maritim (2013) & Credit risk & $\begin{array}{l}\text { A positive relationship found between credit risk } \\
\text { management and financial performance. }\end{array}$ \\
\hline 29 & Fredrick (2012) & 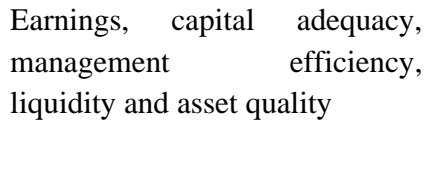 & $\begin{array}{l}\text { Earnings had a strong relationship with financial } \\
\text { performance and that capital adequacy, management } \\
\text { efficiency, liquidity and asset quality had a weak } \\
\text { relationship with financial performance. }\end{array}$ \\
\hline 30 & $\begin{array}{l}\text { Tafri, Hamid, Meera, and } \\
\text { Omar (2009) }\end{array}$ & Credit risk & Significant impact on performance \\
\hline
\end{tabular}

The above table provides testimony of mixed trends on the impact of financial risk management practices on financial performance of organizations in banking and other sectors. To summarize, studies on financial risk management and its effect on financial performance by Noor, (2019); Matayo and Muturi (2018); Wamalwa and Mukanzi (2018); Balungi (2018); Serwadda (2018); Kalu, Shieler and Amu, (2018); Bagh, Khan, and Sadaf, (2017); Harelimana, (2017); Saeed and Zahid (2016); Perinpanathan and Vijeyaratnam (2015); Iyakaremye (2015); Adekunle, Alalade, Agbatogun and Abimbola (2015); Haque and Wani, (2015); Alshatti (2015); Nair, Purohit and Choudhary (2014); Mwangi (2014); Maritim (2013); Tafri, Hamid, Meera, and Omar (2009), revealed a statistically significant positive impact of credit risk management on financial performance. A positive relationship signifies that effective credit risk management results in less credit risk, which leads to increased profits (Li \& Zou 2014).

Other studies by Mardiana and Dianata, (2018); Lelgo and Obwogi (2018); Juma and Atheru (2018); Yousfi (2015); Muteti, (2014), Adeusi, Akeke, Adebisi \& Oladunjoye, (2014), on the other hand, concluded a negative impact of credit risk on financial performance. A negative insignificant relationship between credit risk and financial performance was detected by Olamide, Uwalomwa, and Ranti (2015) and a weak relationship was noted by Fredrick (2012).

Market risk component of financial risk management was also found to have mixed impact on financial performance. A statistically significant positive impact was found by Noor, (2019); Matayo and Muturi (2018); Mudanya and Muturi (2018); Lelgo and Obwogi (2018); Juma and Atheru (2018); Bagh, Khan, and Sadaf, (2017); Harelimana, (2017); 
Yousfi (2015); Alshatti (2015); Mwangi (2014) on financial performance by market risk management. The implication is that well-organized market risk management leads to improved financial performance.

A negative impact was highlighted in the studies by Shetty and Yadav (2019); Juma and Atheru (2018); Muteti, (2014). No significant impact of market risk management on financial performance was noticed by Wamalwa and Mukanzi (2018) and Haque and Wani, (2015).

Findings on the impact of liquidity risk as an important component of financial risk management practices on performance also disclosed mixed results. A statistically significant positive effect was found in the studies by Mudanya and Muturi (2018); Lelgo and Obwogi (2018); Juma and Atheru (2018); Bagh, Khan, and Sadaf, (2017); Chipa and Wamiori's (2017); Harelimana, (2017); Olamide, Uwalomwa, and Ranti, (2015); Arif and Showket, (2015); Mwangi (2014); Adeusi, Akeke, Adebisi \& Oladunjoye, (2014). A positive impact of liquidity risk management on financial performance indicates that efficient liquidity risk management leads to increased profitability.

Other studies by Mardiana and Dianata, (2018); Perinpanathan and Vijeyaratnam (2015); Yousfi (2015). Muteti (2014) provided evidence of statistically significant negative impact of liquidity risk management on financial performance, while Fredrick (2012) noted a weak relationship. Studies by Wamalwa and Mukanzi (2018), and Haque and Wani, (2015), underscored an insignificant effect on financial performance.

In view of the above observations, the current study focused on identifying the most common types of risks that form part of financial risk management and measure their influence on the financial performance of commercial banks in Botswana. It may also be noted that very limited research has been conducted in Botswana on this topic. This study, therefore, is tailored to fill the research gap that currently exists in Botswana and to offer recommendations to the banking sector and risk management policy makers on how to manage the components of financial risk management so as to yield more profits.

\section{Methodology}

\subsection{Research Design, Data Source and Sampling}

The study is premised on evaluating the effect the financial risk management on financial performance of all commercial banks in Botswana. The study has adopted a panel data methodology (2011-2018) and an analytical and descriptive research design. The study sourced monthly secondary data from Bank of Botswana Financial Statistics (BFS) database. It covered an eight-year monthly data from January 2011 to December 2018. This dataset has resulted in a total of 96 observations $\left(8^{*} 12\right)$. Convenience-sampling technique was applied based on data availability for all the variables under study.

Secondary data collected comprised of aggregate data for a population of all commercial banks in Botswana for the period under study. There are currently 10 commercial banks operating in Botswana and these are; African Banking Corporation of Botswana Limited (trading as 'BancABC'), Bank Gaborone Limited, Bank of Baroda (Botswana) Limited, Bank of India (Botswana) Limited, Barclays Bank of Botswana Limited, Capital Bank Limited, First National Bank of Botswana Limited, Stanbic Bank Botswana Limited, Standard Chartered Bank Botswana Limited, and State Bank of India (Botswana) Limited (Bank of Botswana, 2019).

\subsection{Conceptual Framework}

Drawing from literature and based on the objectives of the study, the following conceptual model has been developed:

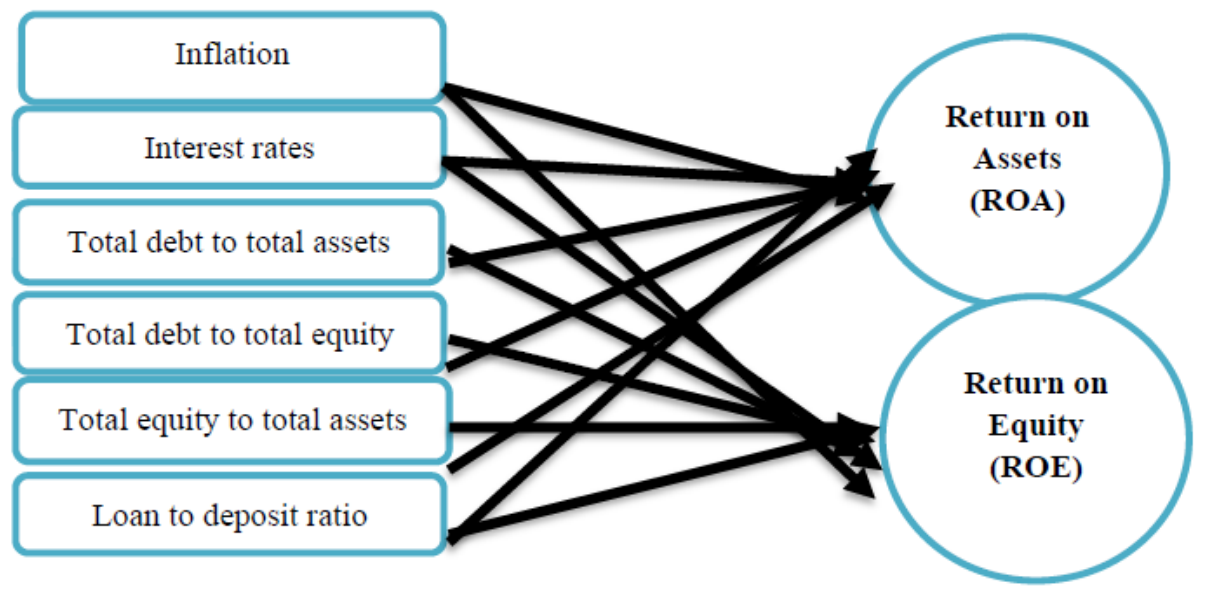

Figure 1. Diagram of Independent \& Dependent variables 


\subsection{Variables and Their Measurements}

The independent variables included ratios that measure financial risk such as market risk, credit risk and liquidity risk and were adopted from similar studies as highlighted in the literature review. Market risk was measured by inflation (INF) and real interest rate (INT), Credit risk was measured by the ratio of total debt to total assets (TDTA) and Total debt to total equity (TDTE), while Liquidity risk was measured by Total equity to total assets (TETA) and loan to deposit ratio (LD). Inflation was measured by consumer price index (CPI) while the real prime rate was used as a proxy for interest rates. Correlation analysis and multiple linear regression techniques were used to assess the significance of the relationship between financial risk management and financial performance of commercial banks in Botswana. Table 2 shows a summary of variables used and their measurements.

Table 2. Variables used and their Measurement

\begin{tabular}{|c|c|c|c|}
\hline Variables & Variable Type & Abbreviation & Measurements \\
\hline \multicolumn{4}{|c|}{ Dependent Variables } \\
\hline Return on Assets & & ROA & Net income / Total Assets \\
\hline Return on Equity & & ROE & Net income/Total Equity \\
\hline \multicolumn{4}{|c|}{ Independent Variables } \\
\hline Inflation & Market risk & INF & Consumer price index (CPI) \\
\hline Interest rates & Market risk & INT & Real prime rate \\
\hline Total debt to total assets & Credit risk & TDTA & Total commercial bank liabilities to total assets \\
\hline Total debt to total equity & Credit risk & TDTE & Total commercial bank liabilities to total equity \\
\hline Total Equity to Total assets & Liquidity risk & TETA & Total commercial bank equity to total assets \\
\hline Loan to deposit ratio & Liquidity risk & $\mathrm{LD}$ & $\begin{array}{l}\text { Total commercial bank loans and advances to total } \\
\text { deposits }\end{array}$ \\
\hline
\end{tabular}

\subsection{Model for Data Analysis}

Model: The regression models are presented in equation 1 and 2:

$$
\begin{aligned}
& \mathrm{ROA}=\alpha+\beta_{1} \mathrm{X}_{1}+\beta_{2} \mathrm{X}_{2}+\beta_{3} \mathrm{X}_{3}+\beta_{4} \mathrm{X}_{4}+\beta_{5} \mathrm{X}_{5}+\beta_{6} \mathrm{X}_{6}+\varepsilon \\
& \mathrm{ROE}=\alpha+\beta_{1} \mathrm{X}_{1}+\beta_{2} \mathrm{X}_{2}+\beta_{3} \mathrm{X}_{3}+\beta_{4} \mathrm{X}_{4}+\beta_{5} \mathrm{X}_{5}+\beta_{6} \mathrm{X}_{6}+\varepsilon
\end{aligned}
$$

Where;

$\mathrm{X} 1=\mathrm{INF} ; \mathrm{X} 2=\mathrm{INT} ; \mathrm{X} 3=\mathrm{TDTA} ; \mathrm{X} 4=\mathrm{TDTE} ; \mathrm{X} 5=\mathrm{TETA} ; \mathrm{X} 6=\mathrm{LD}$;

$\alpha=$ constant; $\mathcal{E}=$ error term

\section{Data Analysis, and Discussion of Findings}

Statistical Package for Social Science (SPSS) was used to analyze the data. Descriptive and inferential statistics were used to analyze the data. Importantly, correlation and regression analysis techniques were applied. In the regression model, financial performance, which is the dependent variable, was measured by Return on Total Assets (ROA) and Return on Equity (ROE) respectively. These financial performance ratios have been used in most studies in the area, for example (Yousfi, 2015). Independent variables comprised of selected financial risk management ratios

\subsection{Descriptive Analysis}

Table 3 is a presentation of the descriptive statistics. The mean value for the return on assets (ROA) is $0.19 \%$ while the return on equity (ROE) recorded a mean value of $1.81 \%$ over the eight-year period. Since the standard deviations for all the variables are small, it shows that the data is not widely dispersed, except Total debt to total equity ratio (TDTE) and Liquidity (LD) which recorded a higher standard deviations of $58.90 \%$ and $9.06 \%$ respectively. 
Distributional property of the data further indicates positive skewness (skewness statistics) for return of asset (Sk $=$ $0.108)$, return on equity $(\mathrm{Sk}=0.144)$, inflation $(\mathrm{Sk}=0.726)$, total debt to total assets $(\mathrm{Sk}=0.770)$ and total debt to total equity $(\mathrm{Sk}=1.048)$. Ratio of total equity to total assets, interest rate and liquidity registered negative skewness. The normal distribution is symmetric and has a skewness of zero. If the distribution of a data set has a negative skewness, then the left tail of the distribution is longer than the right tail. Thus, positive skewness implies that the right tail of the distribution is longer than the left. Therefore, the data is to a greater extent, positively skewed.

Meanwhile kurtosis, which measures the thickness of the tail ends of a distribution in relation to the tails of the normal distribution, was positive for all variables except return on assets $(\mathrm{kt}=-0.1750)$ and interest rates $(\mathrm{kt}=-0.3440)$. The normal distribution has a kurtosis of three, which indicates that the distribution has neither fat nor thin tails. Consequently, if an observed distribution has a kurtosis greater than three, the distribution have heavy tails when compared to the normal distribution. Since all the kurtosis coefficients in Table 3 are less than 3, the data have thin tails when compared to the normal distribution.

Table 3. Descriptive Statistics

\begin{tabular}{lcccccccccc}
\hline & $\mathrm{N}$ & Minimum & Maximum & Mean & Std. Deviation & \multicolumn{2}{c}{ Skewness } & \multicolumn{2}{c}{ Kurtosis } \\
& & & & & & & Std. & \\
& Statistic & Statistic & Statistic & Statistic & Statistic & Statistic & Error & Statistic & Std. Error \\
\hline ROA & 96 & -0.0003 & 0.0040 & 0.0019 & 0.0083 & 0.1080 & 0.2460 & -0.1750 & 0.4880 \\
ROE & 96 & -0.0030 & 0.0380 & 0.0181 & 0.0074 & 0.1440 & 0.2460 & 0.1760 & 0.4880 \\
INF & 96 & 0.2600 & 0.0920 & 0.0484 & 0.0214 & 0.7260 & 0.2460 & 1.0780 & 0.4880 \\
INT & 96 & 0.0165 & 0.0574 & 0.0372 & 0.0086 & -0.2730 & 0.2460 & -0.3440 & 0.4880 \\
TDTA & 96 & 0.8790 & 0.9090 & 0.8924 & 0.0064 & 0.7700 & 0.2460 & 0.2050 & 0.4880 \\
TDTE & 96 & 7.2710 & 9.9730 & 8.3299 & 0.5890 & 1.0480 & 0.2460 & 0.6520 & 0.4880 \\
TETA & 96 & 0.0910 & 0.1210 & 0.1076 & 0.0064 & -0.7700 & 0.2460 & 0.2050 & 0.4880 \\
LD & 96 & 0.5340 & 0.8760 & 0.7683 & 0.0906 & -1.1800 & 0.2460 & 0.2870 & 0.4880 \\
\hline
\end{tabular}

\subsection{Correlation Analysis}

Table 4. Correlations

\begin{tabular}{|c|c|c|c|c|c|c|c|c|c|}
\hline & & ROA & ROE & INF & INT & TDTA & TDTE & TETA & LD \\
\hline $\mathrm{ROA}$ & $\begin{array}{l}\text { Pearson Correlation } \\
\text { Sig. (2-tailed) }\end{array}$ & 1 & & & & & & & \\
\hline ROE & Pearson Correlation & $\begin{array}{c}0 \\
.916^{* *}\end{array}$ & 1 & & & & & & \\
\hline & Sig. (2-tailed) & .000 & & & & & & & \\
\hline INF & $\begin{array}{l}\text { Pearson Correlation } \\
\text { Sig. (2-tailed) }\end{array}$ & $\begin{array}{c}0.646^{* * *} \\
.000\end{array}$ & $\begin{array}{c}0.780^{* * *} \\
.000\end{array}$ & 1 & & & & & \\
\hline INT & $\begin{array}{l}\text { Pearson Correlation } \\
\text { Sig. (2-tailed) }\end{array}$ & $\begin{array}{c}-0.459^{* * *} \\
.000\end{array}$ & $\begin{array}{c}-0.566^{* *} \\
.000\end{array}$ & $\begin{array}{r}-0.658^{* *} \\
.000\end{array}$ & 1 & & & & \\
\hline TDTA & $\begin{array}{l}\text { Pearson Correlation } \\
\text { Sig. (2-tailed) }\end{array}$ & $\begin{array}{r}0.346^{* * *} \\
.001\end{array}$ & $\begin{array}{c}0.554^{* * *} \\
.000\end{array}$ & $\begin{array}{r}0.689^{* *} \\
.000\end{array}$ & $\begin{array}{r}-0.545^{* *} \\
.000\end{array}$ & 1 & & & \\
\hline TDTE & $\begin{array}{l}\text { Pearson Correlation } \\
\text { Sig. (2-tailed) }\end{array}$ & $\begin{array}{c}0.350^{* *} \\
.000\end{array}$ & $\begin{array}{l}0.555^{* *} \\
.000\end{array}$ & $\begin{array}{r}0.701^{* * *} \\
.000\end{array}$ & $\begin{array}{r}-0.558^{* * *} \\
.000\end{array}$ & $\begin{array}{r}0.996^{* *} \\
.000\end{array}$ & 1 & & \\
\hline TETA & $\begin{array}{l}\text { Pearson Correlation } \\
\text { Sig. (2-tailed) }\end{array}$ & $\begin{array}{r}-0.346^{* * *} \\
.001\end{array}$ & $\begin{array}{c}-0.554^{* *} \\
.000\end{array}$ & $\begin{array}{r}-.689^{* *} \\
.000\end{array}$ & $\begin{array}{r}-0.545^{* *} \\
.000\end{array}$ & $\begin{array}{r}-1.000^{* *} \\
.000\end{array}$ & $\begin{array}{r}-0.996^{* *} \\
.000\end{array}$ & 1 & \\
\hline LD & $\begin{array}{l}\text { Pearson Correlation } \\
\text { Sig. (2-tailed) }\end{array}$ & $\begin{array}{c}-0.456^{* *} \\
.000\end{array}$ & $\begin{array}{c}-0.640^{* *} \\
.000\end{array}$ & $\begin{array}{r}-0.875^{* *} \\
.000\end{array}$ & $\begin{array}{r}-0.583^{* *} \\
.000\end{array}$ & $\begin{array}{r}-0.838^{* *} \\
.000\end{array}$ & $\begin{array}{r}-0.845^{* *} \\
.000\end{array}$ & $\begin{array}{r}0.838^{* * *} \\
.000\end{array}$ & 1 \\
\hline & $\mathrm{N}$ & 96 & 96 & 96 & 96 & 96 & 96 & 96 & 96 \\
\hline
\end{tabular}

**. Correlation is significant at the 0.01 level (2-tailed).

*. Correlation is significant at the 0.05 level (2-tailed).

The correlation analysis shows the direction and size of the relationship between the data variables. The correlation results are presented in Table 4. All the twenty-eight correlation relationships were strong at $1 \%$ level; seventeen of the relationships were negatively correlated whilst the other eleven relationships were positively correlated. The return on assets (ROA) is positively and significantly correlated with return on equity (ROE) $(\mathrm{r}=0.916)$. This outcome is 
expected since ROA and ROE are theoretically directly related, and this relationship is determined by the equity multiplier (EM), which is the amount of assets per dollar of equity capital (Mishkin and Eakins, 2012).

There were positive and significant correlations at $1 \%$ level found between ROA and inflation $(r=0.646, p=0.000)$, TDTA $(\mathrm{r}=0.346, \mathrm{p}=0.001)$ and TDTE $(\mathrm{r}=0.350, \mathrm{p}=0.000)$. ROA had negative and significant correlations with INT $(\mathrm{r}=-0.459, \mathrm{p}=0.000)$, TETA $(\mathrm{r}=-0.346, \mathrm{p}=0.001)$ and liquidity $(\mathrm{r}=-0.456, \mathrm{p}=0.000)$.

ROE had positive and significant correlations at $1 \%$ level with inflation $(r=0.780, p=0.000)$, TDTA $(r=0.554, p=0.000)$ and TDTE $(\mathrm{r}=0.555, \mathrm{p}=0.000)$, and negative and significant relationships were observed with interest rates $(\mathrm{r}=-0.566$, $\mathrm{p}=0.000)$, TETA $(\mathrm{r}=-0.554, \mathrm{p}=0.000)$ and liquidity $(\mathrm{r}=-0.640, \mathrm{p}=0.000)$.

In terms of cross-correlations among the independent variables, strong correlations were found amongst all the independent variables at $1 \%$ level. It is worth-noting that when there exist highly correlated independent variables in the model, then multi-collinearity effects are said to exist (Zainodin et al, 2011). The dangers to multicollinearity are that it reduces the precision of the estimate coefficients, which in turn weakens the statistical power of the regression model. Multicollinearity constitutes a threat, both to the proper specification and the effective estimation of the type of structural relationship commonly sought through the use of regression techniques (Farrar \& Glauber, 1967).

\subsection{Regression Analysis}

\subsubsection{Multicollinearity}

Daoud (2017) defines Multicollinearity as a situation in statistics, when two or more independent variables in multiple regression models are highly correlated. According to Saunders et al. (2012), the simplest diagnostic is to use the correlation coefficients, extreme collinearity being represented by a correlation coefficient of 1 . The rule of the thumb is that the presence of high correlations, which is generally anything above 0.90 , indicates substantial collinearity. The independent variables that are highly correlated must be dropped from the model. The Variance Inflation Factors (VIFs) were calculated for all the independent variables and, Inflation, Total debt to Total equity and Total equity to Total Assets had VIFs > 5. The three independent variables were dropped from the two regression models. These variables were excluded as their effect can be perfectly predicted from one or more of other independent variables and therefore, considered redundant.

Table 5. Regression Results on the two dependent variables

\begin{tabular}{|c|c|c|c|c|c|c|c|c|}
\hline \multirow[t]{2}{*}{ VARIABLE } & & & \multicolumn{3}{|c|}{ ROA } & \multicolumn{3}{|c|}{ ROE } \\
\hline & $\begin{array}{c}\text { Collinearity } \\
\text { Tolerance } \\
\end{array}$ & $\begin{array}{c}\text { Statistics } \\
\text { VIF } \\
\end{array}$ & Coefficient & t-stat. & Sig. & Coefficient & t-stat. & Sig. \\
\hline Constant & & & 0.027 & 1.337 & 0.185 & 0.052 & 0.344 & 0.731 \\
\hline INT & 0.650 & 1.540 & -0.307 & -2.787 & 0.006 & -0.293 & -3.097 & 0.003 \\
\hline TDTA & 0.294 & 3.405 & -0.178 & -1.087 & 0.280 & 0.004 & 0.031 & 0.975 \\
\hline LD & 0.276 & 3.626 & -0.426 & -2.520 & 0.013 & -0.465 & -3.207 & 0.002 \\
\hline $\mathbf{R}^{2}$ & & & 0.274 & & & 0.466 & & \\
\hline Adjusted $\mathbf{R}^{2}$ & & & 0.250 & & & 0.448 & & \\
\hline
\end{tabular}

\subsubsection{Dependent Variable: Return on Assets (ROA)}

The regression model measured the impact of the independent variables of INT, TDTA and LD on the dependent variable of ROA. The regression output is shown in Table 5.

The model had an $\mathrm{R}^{2}$ of 0.274 , which implies that the changes to return on assets of $27.4 \%$ can be explained by the three independent variables, Interest rates, Total debt to total assets ratio and Liquidity.

The results show statistically significant negative relationships for Interest rates and Liquidity with return on assets. TDTA have a negative but statistically insignificant relationship with return on assets. The regression coefficients for INT, TDTA and Liquidity are $-0.307,-0.178$, and -0.426 respectively. The $p$-values of predictor variables were INT, $p=0.006$, TDTA, $\mathrm{p}=0.280$ and Liquidity, $\mathrm{p}=0.013$. These results imply that an increase of INT, TDTA and Liquidity has a negative effect on ROA.

The outcomes are in agreement with the findings of Lelgo and Obwogi (2018) who concluded that interest rate risk negatively influenced the ROA. The findings of Wamalwa and Mukanzi (2018) indicate interest rate risk had a negative relationship with no significant impact on return on assets. However, the findings are not consistent with the results of Juma and Atheru (2018) and Yousfi (2015) who concluded that interest rate risk had positive and significant effect on ROA. The study's outcomes are in agreement with the findings of Lelgo and Obwogi (2018), Juma and Atheru (2018), Yousfi (2015) and Tafri, Hamid, Meera, and Omar (2009) who concluded that credit risk negatively influenced the ROA. 
However, the study's findings are not consistent with the results of Noor (2018), Kalu, Shieler and Amu, (2018) and Wamalwa and Mukanzi (2018) who concluded that credit risk had positive and significant effect on ROA.

The findings of Yousfi (2015) indicate liquidity risk management had a negative and significant relationship with return on assets that is in line with study's findings. However, the findings of the study are not consistent with the results of Lelgo and Obwogi (2018), Juma and Atheru (2018), Noor (2019) and Adeusi, Akeke, Adebisi \& Oladunjoye, (2014) who concluded that liquidity risk had a positive impact on ROA. Tafri, Hamid, Meera, and Omar (2009) concluded that that liquidity risk does not have an impact on the return on assets of commercial banks.

\subsubsection{Dependent Variable: Return on Equity (ROE)}

The regression model measured the impact of the independent variables of INT, TDTA and LD on the dependent variable of ROE. The regression output is shown in Table 5.

The model had an $\mathrm{R}^{2}$ of 0.466 , which implies that the changes to return on equity of $46.6 \%$ can be explained by the three independent variables, Interest rates, Total debt to total assets ratio and Liquidity.

The results show statistically significant negative relationships for Interest rates and Liquidity with return on equity. However, Total debt to total assets ratio has a positive but statistically insignificant relationship with the dependent variable, viz. return on equity. The regression coefficients for INT, TDTA and Liquidity are $-0.293,0.004$, and -0.465 respectively. The $p$-values of predictor variables were INT, $p=0.003$, TDTA, $p=0.975$ and Liquidity, $p=0.002$. These results imply that an increase of INT and Liquidity has a negative effect on ROE whilst Total debt to total assets has a positive effect.

The findings of the study are consistent with the results of Tafri, Hamid, Meera, and Omar (2009) who concluded that interest risk had negative and significant effect on ROE. However, the findings Harelimana (2017) and Yousfi (2015) indicate that interest rate risk had a positive and significant effect on ROE, which differs with results of the study.

The findings of the study are consistent with the results of Kalu, Shieler and Amu (2018) and Harelimana, (2017) who concluded that credit risk had positive effect on ROE. However, the results of the study are not consistent with findings of Yousfi (2015) and Tafri, Hamid, Meera, and Omar (2009) that established a negative and significant for credit risk with return on equity.

The results are in line with the findings of Yousfi (2015) who found that liquidity risk had a negative and significant relationship with return on equity. However, the results of the study are not consistent with findings of Adeusi, Akeke, Adebisi and Oladunjoye (2014) that established a positive and insignificant relationship for liquidity risk with return on equity. According to Harelimana (2017), liquidity has a positive and significant relationship with return on equity, which is not in line with the results of this study. Tafri, Hamid, Meera, and Omar (2009) concluded that that liquidity risk does not have an impact on the return on equity of commercial banks.

\subsection{Hypotheses Tests}

Table 6. Summary of accepted/rejected hypothesis

\begin{tabular}{|l|l|l|}
\hline Hypothesis & \multicolumn{1}{|c|}{ Statement } & Results \\
\hline $\mathrm{H}_{1}$ & $\begin{array}{l}\text { Market Risk management practices have a negative and significant statistical impact } \\
\text { on the financial performance of commercial banks in Botswana. }\end{array}$ & Accepted \\
\hline $\mathrm{H}_{2}$ & $\begin{array}{l}\text { Credit Risk management practices have a negative and significant statistical impact on } \\
\text { the financial performance of commercial banks in Botswana. }\end{array}$ & Rejected \\
\hline $\mathrm{H}_{3}$ & $\begin{array}{l}\text { Liquidity Risk management practices have a negative and significant statistical impact } \\
\text { on the financial performance of commercial banks in Botswana. }\end{array}$ & Accepted \\
\hline
\end{tabular}

Market risk management practices measured by interest rates (real prime rate) had a negative and significant effect on return on assets and return on equity.

Credit risk management practices measured by total debt to total assets ratio had a negative and insignificant effect on return on assets. However, total debt to total assets ratio had a positive and insignificant effect on return on equity.

Liquidity risk management practices measured by commercial bank loans and advances to total deposits ratio (liquidity) had a negative and significant effect on return on assets and return on equity. 


\section{Conclusion and Recommendation}

The main purpose of this study was to assess the role played by risk management practices on financial performance of commercial banks in Botswana. Risk management was assessed in terms of financial risk management, and in particular; credit risk, liquidity risk and market risk in line with Matayo and Muturi (2018) and financial performance was measured by return on assets and return on equity. Negative and significant relationships were expected among the three risk management practices with financial performance. The conclusions were as follows:

In terms of liquidity risk management, a negative and significant relationship was established with financial performance and the findings are in line with the results of Yousfi (2015). However, the results of the study are in disagreement with findings of Adeusi, Akeke, Adebisi \& Oladunjoye (2014) that established a positive relationship for liquidity risk with financial performance. Therefore, the implications are that when liquidity risk management practices increase, bank's financial performance goes down. This is due to the fact that greater emphasis and oversight placed on risk management at banks ends up reducing their performance, hence there is an evidence of a tradeoff between safety and financial performance.

Similarly, negative and significant relationships were obtained between market risk measured using interest rate and banks financial performance, indicating that the increase of market risk management practice has resulted in reduced financial performance for commercial banks. However, the findings are not in line with Yousfi (2015), who concluded that interest rate risk had a positive and significant effect on financial performance.

However, credit risk management practices had mixed results by having a negative and insignificant relationship with return on assets in agreement with the findings of Lelgo and Obwogi (2018), Juma and Atheru (2018), Yousfi (2015) and Tafri, Hamid, Meera, and Omar (2009). A positive and insignificant relationship with return on equity in agreement with Kalu, Shieler and Amu (2018) and Harelimana, (2017) who concluded that credit risk had positive effect on ROE. As a result, the outcome of credit risk management on bank financial performance remains inconclusive in this study.

The implication of these findings are that banks should strike a proper balance between risk management practices and financial performance, so that any risk management practices performed by banks should yield more profits. Based on the outcome of this study, we recommend that banks engage in appropriate market, credit, and liquidity risk management efforts that will yield profits for the banks.

\subsection{Limitations \& Directions for Future Research}

Future research could consider more independent variables to adequately capture the effect of financial risk management on the performance of commercial banks in Botswana. Further, an expanded dataset that captures the pre-crisis period of 2008 and the post-crisis could be included to capture any structural differences in the dataset. This expanded dataset could also capture the development of new legislations such as the Basel Accords and any moratoriums induced in the Botswana banking sector in order to shed more light of their impacts on the financial performance of commercial banks.

\section{References}

Adekunle, O., Alalade, S. Y., Agbatogun, T., \& Abimbola, C. (2015). Credit risk management and financial performance of selected commercial banks in Nigeria. Journal of Economic \& Financial Studies, 3(01), 01-09. https://doi.org/10.18533/jefs.v3i01.73

Adeusi, S. O., Akeke, N. I., Adebisi, O. S., \& Oladunjoye, O. (2014). Risk management and financial performance of banks in Nigeria. Risk Management, 6(31).

Alshatti, A. S. (2015). The effect of credit risk management on financial performance of the Jordanian commercial banks. Investment Management and Financial Innovations, 12(1), 338-345.

Arif, A., \& Showket, A. (2015). Relationship between financial risk and financial performance: An insight of Indian insurance industry. International Journal of Science and Research, 4(11), 1424-1433. https://doi.org/10.21275/v4i11.12111504

Bagh, T., Khan, M. A., \& Sadaf, R. (2017). The Underlying Impact of Risk Management Practices on Banks Financial Performance: An Empirical Analysis on Financial Sector of Pakistan. International Journal of Research in Business Studies and Management, 4(7), 10-23.

Baldwin, C., \& Scott, M. (1983). The resolution of claims in financial distress: The Case of Massey Ferguson', Journal of Finance, 38(2), 505-516. https://doi.org/10.1111/j.1540-6261.1983.tb02258.x

Balungi, D. (2018). Credit Risk Management and Performance of Financial Institutions in Uganda: A Case Study of Housing Finance Bank, Kampala Branch. https://doi.org/10.14807/ijmp.v9i1.658 
Bank of Botswana. (2018). Annual Report. Retrieved November 19, 2019, from http://www.bankofbotswana.bw/assets/uploaded/BoB\%202018\%20Annual\%20Report\%20Main\%20document.pdf

Bank of Botswana. (2018). Banking Supervision Annual Report. Retrieved November 19, 2019, from http://www.bankofbotswana.bw/assets/uploaded/Banking\%20Supervision\%20Annual 20Report\%202018_2.pdf

Bank of Botswana. (2019). Commercial Banks. Retrieved June 17, 2019, form http://www.bankofbotswana.bw/content/2009103015021-banks

Bank of International Settlements. (2011). Basel III: A global regulatory framework for more resilient banks and banking system. Retrieved from https://www.bis.org/publ/bcbs189.pdf

Bank of International Settlements. (2018). Structural changes in banking after the crisis. Report prepared by a Working Group established by the Committee on the Global Financial System. CGFS Papers. No 60. 24 January 2018

Bruegge, B., \& A. H. Dutoit (2000). Object-Oriented Software Engineering: Conquering Complex and Changing Systems. Upper Saddle River, NJ, Prentice Hall.

Carey, A. A. (2001).Effective Risk Management in Financial Institutions: The turnbull approach. Journal of Applied Business Research, 9(3), 24-27. https://doi.org/10.1108/09657960110696014

Chipa, E. M., \& Wamiori, G. (2017). Effects of Risk Management on Financial Performance of Insurance Companies in Mombasa County Kenya. Imperial Journal of Interdisciplinary Research, 3(5), 259-282

Daoud, J. I. (2007). Multicollinearity and Regression Analysis. Journal of Physics: Conf. Series, 949(2017) https://doi.org/10.1088/1742-6596/949/1/012009

El-Chaarani, H. (2019). Determinants of bank liquidity in the Middle East region. International Review of Management and Marketing, 9(2), 64.

Farrar, D. E., \& Glauber, R. R. (1967). Multicollinearity in regression analysis: the problem revisited. The Review of Economic and Statistics, 92-107. https://doi.org/10.2307/1937887

Fredrick, O. (2012). The Impact of Credit Risk Management on Financial Performance of Commercial Banks in Kenya. DBA Africa Management Review, 3(1), 22-37.

Haque, S. M., \& Wani, A. A. (2015). Relevance of financial risk with financial performance: An insight of Indian banking sector. Pacific Business Review International, 8(5), 54-64.

Harelimana, J. B. (2017). The Role of Risk Management on Financial Performance of Banking Institutions in Rwanda. Global Journal of Management and Business Research, 8(1), 1-5.

Hawkins, J., \& Mihaljek, D (2001). The banking industry in the emerging market economies: competition, consolidation and systemic stability - an overview. BIS Papers No. 4, 1-44.

Ibe, S. O. (2013). The impact of liquidity management on the profitability of banks in Nigeria. Journal of Finance and Bank Management, 1(1), 37-48.

Iyakaremye, A. (2015). Analysis Of Financial Performance And Financial Risk In Agricultural Companies Listed On The Nairobi Security Exchange (Doctoral dissertation, United States International University-Africa).

Juma, A. M., \& Atheru, G. (2018). Financial Risks Analysis and Performance of Commercial Banks in Kenya. Journal of Finance and Accounting, 2(2), 76-95.

Kalu, E. O., Shieler, B., \& Amu, C. U. (2018). Credit risk management and financial performance of microfinance institutions in Kampala, Uganda. Independent journal of management \& production, 9(1), 153-169. https://doi.org/10.14807/ijmp.v9i1.658

Lelgo, K. J., \& Obwogi, J. (2018). Effect of financial risk on financial performance of micro finance institutions in Kenya. International Academic Journal of Economics and Finance, 3(2), 357-369

Li, F., \& Zou, Y. (2014). The impact of Credit risk management on profitability of commercial banks: A study of Europe. UMEA School of Business and Economics.

Mardiana, M., \& Dianata, A. W. M. (2018). The effect of risk management on financial performance with good corporate governance as a moderation variable. Management and Economics Journal (MEC-J), 257-268. https://doi.org/10.18860/mec-j.v0i0.5223

Maritim, K. J. (2013). Relationship between Credit Risk Management Practices and Financial Performance of Micro Finance Institutions in Kenya. A Research Project Report submitted in partial fulfilment of the requirements for the award of the Degree of Master of Business Administration, School of Business, University of Nairobi. 
Matayo, W., \& Muturi, W. (2018). Effect of Financial Risk on Financial Performance of Large Scale Supermarkets in Nairobi County, Kenya. International Journal of Social Sciences and Information Technology, 4(10), 574-591.

Mishkin, .F. S., \& Eakins, S. G. (2012).Financial Markets and Institutions, 7th edition. Pearson Education Limited.

Mudanya, L. E., \& Muturi, W. (2018). Effects of Financial Risk on Profitability of Commercial Banks Listed in the Nairobi Securities Exchange. International Journal of Social Sciences Management and Entrepreneurship, 2(1), 75-93. https://doi.org/10.32898/ibmj.01/1.1 article14

Muteti, S. R. (2014). Relationship between financial risk management and financial performance of commercial banks in Kenya. Kenya: A Research Project, College of Humanities and Social Sciences.

Mutukua, C. (2016). Unpublished MBA- research project submitted in partial fulfilment of the requirements for the award of the degree of Masters in Business Administration, School of Business, University of Nairobi.

Mwangi, Y. K. (2014). The Effect of Risk Management on Financial Performance of Commercial Banks in Kenya. A Research Project Submitted in Partial Fulfilment of the requirements for the Award of The Degree of Master of Science in Finance, School of Business, University of Nairobi.

Nair, G. K., Purohit, H., \& Choudhary, N. (2014). Influence of risk management on performance: An empirical study of international Islamic bank. International Journal of Economics and Financial Issues, 4(3), 549-563.

Noor, J. A. M. (2019). Effect of Financial Risk on Performance of Transport Firms in Mombasa County (Doctoral dissertation, JKUAT-COHRED).

Olalekan, L. I., Olumide, M. L., \& Irom, I, M. (2018). Financial Risk Management and the Profitability: An Empirical Evidence from Commercial Banks in Nigeria. Journal of Management Sciences University.

Olamide, O., Uwalomwa, U., \& Ranti, U. O. (2015). The Effect of Risk Management on Bank's Financial Performance in Nigeria. Journal of Accounting and Auditing, 1-7. https://doi.org/10.5171/2015.313679

Paulinus, E. C., \& Jones, A. S. (2017). Financial Risk Management and Corporate Performance of Deposit Money Banks in Nigeria. Archives of Business Research, 5(12), 78-87.

Perinpanathan, R., \& Vijeyaratnam, H. (2015, June). The Impact of Credit Risk Management on Financial Performance A Study of State Commercial Banks in Sri Lanka. In Proceedings of International Conference on Contemporary Management.

Saeed, M. S., \& Zahid, N. (2016). The impact of credit risk on profitability of the commercial banks. Journal of Business \& Financial Affairs, 5(2), 2167-0234. https://doi.org/10.4172/2167-0234.1000192

Saunders, M., Lewis, P., \& Thornhill, A. (2007). Research methods. Business Students.

Serwadda, I. (2018). Impact of Credit Risk Management Systems on the Financial Performance of Commercial Banks in Uganda. Acta Universitatis Agriculturae et Silviculturae Mendelianae Brunensis, 66(6), 1627-1635. https://doi.org/10.11118/actaun201866061627

Shah, A. (2014). The Political Economy of Financial Risk. A Case Study of HBOS, University of Suffolk, forthcoming.

Shetty, C., \& Yadav, A. S. (2019). Impact of Financial Risks on the Profitability of Commercial Banks in India. Shanlax International Journal of Management, 7(1), 25-35. https://doi.org/10.34293/management.v7i1.550

Sinha, A. (2011). Financial Sector Regulation and Implications for Growth. Bank of International Settlements Paper 62

Sundharam, K. P. M., \& Varshney P. N. (2002). Banking and Financial System. Sultan Chand and Sons, New Delhi.

Tafri, F. H., Hamid, Z., Meera, A. K. M., \& Omar, M. A. (2009). The impact of financial risks on profitability of Malaysian commercial banks: 1996-2005. International Journal of Social, Human Science and Engineering, 3(6), 268-282.

Wamalwa, M. F., \& Mukanzi, C. (2018). Influence of Financial Risk Management Practices on Financial Performance of Commercial Banks in Kenya, A Case of Banks in Kakamega County. The Strategic Journal of Business \& Change Management, 5(4), 1040-1056.

Wanjohi, J. G., Wanjohi, G., \& Ndambiri, M. (2013). The effect of financial risk management on the financial performance of commercial banks in Kenya. Unpublished MBA Project.

Whitaker, R. B. (1999). The early stages of financial distress. Journal of Economics and Finance, 23(2), 123-132. https://doi.org/10.1007/BF02745946

Yousfi, I. (2015). Risk Management Practices and Financial Performance in Jordan: Empirical Evidence from Islamic Banks. 
Zainodin, H. J., Noraini, A., \& Yap, S. J. (2011). An alternative multicollinearity approach in solving multiple regression problem. Trends in Applied Sciences Research, 6(11), 1241-1255. https://doi.org/10.3923/tasr.2011.1241.1255

\section{Copyrights}

Copyright for this article is retained by the author(s), with first publication rights granted to the journal.

This is an open-access article distributed under the terms and conditions of the Creative Commons Attribution license which permits unrestricted use, distribution, and reproduction in any medium, provided the original work is properly cited. 